\title{
Model Sistem Dinamik Untuk Meningkatkan Rasio Pemenuhan dan Efisiensi Pada Manajemen Rantai Pasok Biodiesel Nasional
}

\author{
Ashma Hanifah dan Erma Suryani \\ Departemen Sistem Informasi, Fakultas Teknologi Informasi, Institut Teknologi Sepuluh Nopember \\ (ITS) \\ e-mail: erma.suryani@is.its.ac.id
}

\begin{abstract}
Abstrak-Permasalahan energi telah menjadi isu global termasuk di Indonesia, dengan meningkatnya standar hidup mengakibatkan adanya peningkatan terhadap kebutuhan energi nasional yang khususnya didominasi oleh sektor transportasi. Pemerintah telah mengeluarkan kebijakan untuk menggunakan bahan bakar alternatif, yaitu biodiesel. Namun saat ini, kondisi pemanfaatan biodiesel dalam negeri masih sangat kecil. Hal ini ditunjukkan oleh rendahnya realisasi pemanfaatan biodiesel yang masih dibawah angka target mandatori. Salah satu hambatan yang dialami, adalah adanya kendala dalam pasokan bahan baku biodiesel, yaitu kelapa sawit. Biaya logistik juga menjadi penghambat ketersediaan dan keterjangkauan Bahan Bakar Nabati (BBN) tersebut, sehingga kini daya saing industri BBN masih dikalahkan oleh BBM. Dengan kondisi seperti itu, dibutuhkan manajemen rantai pasok yang lebih efektif dan efisien dengan fokus memenuhi ketersediaan biodiesel yang terjangkau, serta mengetahui faktorfaktor apa saja yang dapat mempengaruhinya. Penelitian ini akan menggunakan metode pemodelan dengan tehnik simulasi sebagai sarana berbasis untuk memahami sistem dalam manajemen rantai pasok, dan mengambil studi kasus industri biodiesel secara global. Pemodelan dibuat dengan tiga tahapan utama. Tahap pertama adalah analisis model sistem. Tahap kedua adalah pembuatan diagram kausatik, dan tahap ketiga adalah mensimulasikan kondisi eksisting rantai pasok beserta rancangan skenarionya hingga tahun 2032. Hasil dari penelitian ini, dari skenario model yang dilakukan pengembangan model rantai pasok biodiesel mampu meningkatkan rasio pemenuhan sebesar $13 \%$ dan mengurangi persentase atau efisiensi biaya logistik sebesar $15,7 \%$.
\end{abstract}

Kata Kunci-Biodiesel, model, manajemen rantai pasok, simulasi, sistem dinamik, rasio pemenuhan, efisien.

\section{PENDAHULUAN}

$\mathrm{B}$ ERDASARKAN buku statistik ekonomi dan energi Indonesia (tahun 2012), terdapat penurunan jumlah cadangan minyak yang dimiliki Indonesia. Pada tahun 1985 tercatat jumlah cadangan minyak sekitar 9,2 milyar barrel, kemudian jumlah tersebut turun pada tahun 2000 menjadi 5,1 milyar barrel, dan pada tahun 2012 berkurang menjadi 3,74 milyar barrel. Sedangkan produksi minyak mentah di Indonesia juga menurun setiap harinya. Semenjak tahun 1998, tercatat produksi minyak mentah yang mencapai angka 1,52 juta barrel perhari (bph), dan terus menurun hingga tahun 2005 yang mencapai jumlah produksi sekitar 1,07 juta bph [1].

Kondisi penggunaan minyak bumi di Indonesia patut menjadi kekhawatiran bagi seluruh masyarakat pengguna energi bumi. Cadangan minyak dan gas bumi di Indonesia diperkirakan tidak akan bertahan selama 25 tahun. Meningkatnya kebutuhan energi Indonesia juga berimplikasi pada meningkatnya urgensi konversi dan diversifikasi energi. Untuk itu, diperlukan suatu usaha diversifikasi sumber energi yang ramah lingkungan dengan memproduksi energi terbaharu (renewable energy) yang dapat menjamin pasokan kebutuhan energi nasional. Selain itu, penghematan pemakaian minyak bumi sebagai sumber energi tak terbaharukan (non-renewable energy) juga harus dilakukan oleh semua pihak. Dalam situasi seperti ini, alternatif sumber energi terbaharukan perlu dipertimbangkan, salah satunya adalah biodiesel yang telah menjadi perhatian serius pemerintah selama ini.

Biodiesel adalah salah satu bahan bakar alternatif yang prospektif untuk digunakan, dikarenakan sumbernya yang berasal dari minyak tumbuhan yang diolah dengan memanfaatkan alkohol sehingga berpotensi untuk menggantikan solar karena kemiripan karakteristiknya. Biodiesel dapat digunakan sebagai pengganti minyak solar karena keduanya mempunyai sifat fisik dan kimia yang hampir sama. Selain itu, biodiesel memiliki keunggulan berupa jenis bahan bakar yang dapat diperbaharui (renewable), mudah untuk diproses, mudah terurai secara alami, dan tidak menghasilkan limbah yang berbahaya bagi lingkungan sekitar. Keunggulan lainnya dari pemakaian biodiesel sebagai bahan bakar adalah nilai emisi yang rendah jika dibandingkan dengan minyak diesel yang dihasilkan dari energi fosil. Selain itu jika subsidi untuk bahan bakar minyak dihapuskan, maka harga ekonomis biodiesel dapat bersaing dengan minyak diesel [2].

Pemanfaatan sumberdaya nabati di Indonesia membutuhkan sebuah pendekatan yang memerhatikan para pemangku kepentingan. Namun, fakta di lapangan menunjukkan bahwa Indonesia masih belum mampu mengembangkan dan memanfaatkan potensi bahan bakar nabati yang ada secara maksimal. Realisasi pemanfaatan biodiesel pada tahun 2009 hanya sebesar $15,4 \%$ dari target mandatori. Pada tahun 2010 realisasi biodiesel menjadi $20,7 \%$ terhadap target mandatori kemudian terus meningkat menjadi $27,7 \%$ terhadap target mandatori. Dari segi pengembangan industri biofuel nasional, menurut Ketua Asosiasi Produsen Biofuels Indonesia (Aprobi) sampai dengan tahun 2008, terdapat penurunan jumlah produsen biofuel sebesar 70\%. Para produsen memutuskan menutup usahanya, karena salah satu permasalahannya adalah adanya ketidakpastian pasokan Bahan Bakar Nabati (BBN)[3]. Ketua Umum Gabungan Pengusaha Perkebunan Indonesia (GPPI) juga memaparkan adanya permasalahan infrastruktur 
yang kurang baik, sehingga biaya logistik menjadi salah satu penghambat dalam hilirisasi rantai pasok biodiesel [4].

Isu biodiesel ini memunculkan adanya kebutuhan untuk membangun model rantai pasok bioenergi. Pemanfaatan sumberdaya nabati serta pengolahan bahan baku hingga menjadi biodiesel, membutuhkan pengelolaan yang terintegrasi. Semua aliran-mulai dari bahan, informasi, dan uangmelibatkan berbagai pihak seperti konsumen biodiesel, pengolah biodiesel, dan juga Pertamina (sebagai BUMN yang menangani pengelolaan minyak dan gas bumi di Indonesia). Masing-masing pihak tersebut memiliki peran dan kepentingan yang berbeda-beda. Hal ini yang memunculkan permasalahan bagaimana supply chain biodiesel diterapkan dengan mempertimbangkan berbagai kepentingan dan pihak-pihak yang terkait. Manajemen rantai pasok menjadi salah satu pendekatan yang relevan untuk diterapkan karena aliran bahan, informasi, dan uang dapat dikelola secara terpadu di sepanjang rantai pasok. Banyaknya jumlah stakeholder yang terlibat, menunjukkan bahwa pelaksanaan pengembangan biodiesel membutuhkan penanganan yang komprehensif dari berbagai sudut pandang, lintas sektoral.

Adapun hasil identifikasi kondisi dan permasalahan yang ada mengenai ketersediaan biodiesel dalam memenuhi target pemenuhan kebutuhan bioenergi pada masyarakat menjadi persoalan atau fokus yang perlu diperhatikan. Di Indonesia, pemanfaatan biodiesel terkendala oleh dua masalah utama, dimana ketersediaan pasokan Bahan Bakar Nabati (BBN) biodiesel mengalami kondisi ketidakpastian dan membutuhkan biaya logistik yang cukup tinggi. Jika melihat komponen biaya dalam operasi suatu industri, biaya logistik merupakan komponen biaya terbesar kedua setelah pembelian bahan. Tingginya biaya logistik menunjukkan belum optimalnya pengelolaan fungsi distribusi fisik. Hal ini pula yang menjadi salah satu kendala dalam mengembangkan pemanfaatan Bahan Bakar Nabati biodiesel di Indonesia. Dampak langsung dari kedua masalah ini adalah BBN akan terus kalah bersaing dengan BBM di dunia industri energi, sehingga rencana diversifikasi energi tidak tercapai. Kedua masalah utama tersebut juga menjadi titik berat permasalahan dalam proses pengadaan biodiesel hingga ke tangan konsumen. Hal ini yang melandasi dibutuhkan adanya evaluasi dari segi efektivitas ketersediaan dan juga efisiensi biaya, agar bahan bakar ini dapat dengan mudah diperoleh, dimanfaatkan, serta terjangkau oleh masyarakat. Efektivitas dibutuhkan agar rasio pemenuhan permintaan akan ketersediaan biodiesel dapat tercukupi dan ditingkatkan, sedangkan efisiensi- selain dibutuhkan agar biaya dan proses yang dikeluarkan sebanding dengan penggunaan sumberdaya (input) yang digunakan - juga berpengaruh dalam menentukan seberapa mahal harga biodiesel ketika tiba di tangan konsumen akhir.

Pada penelitian ini, solusi yang ditawarkan adalah dengan menggunakan pemodelan dan simulasi sebagai alat penyediaan dukungan untuk perencanaan, analisa, dan evaluasi sistem menggunakan model simulasi dinamik. Melalui model simulasi dinamik, analisis pada sistem dapat dilakukan dengan mempertimbangkan data historis yang ada, serta merancang skenario yang diperkirakan dapat memperbaiki kondisi rantai pasok biodiesel saat ini. Diharapkan dengan hal tersebut, selain mampu mengatasi permasalahan yang ada dan dapat membantu pencapaian target mandatori dari pemerintah, dapat juga mengoptimalkan penggunaan biodiesel sebagai bahan bakar terbaharukan. Akhir dari penulisan ini akan diperoleh usulanusulan terkait ketersediaan energi (biodiesel) untuk meningkatkan rasio pemenuhan dan efisiensinya dalam manajemen rantai pasok.

\section{DASAR TEORI}

\section{A. Manajemen Rantai Pasok}

Supply Chain Management (SCM) atau yang biasa disebut dengan manajemen rantai pasok, merupakan proses pengelolaan rencana, desain, dan kontrol dari alur/ arus informasi serta material selama proses supply chain yang ada bertemu dengan permintaan konsumen. SCM berguna untuk mengefisiensikan alur rantai pasok yang ada dengan permintaan konsumen, baik pada saat ini maupun masa mendatang [5]. Adapun manfaat lain dari manajemen rantai pasok adalan untuk mengintegrasikan supplier, industri manufaktur, warehouse, jasa, pengecer, dan konsumen secara efisien [6]. Sehingga barang maupun jasa dapat terdistribusi dalam jumlah, waktu, serta lokasi yang tepat. Biaya yang dikeluarkan pun dapat diminimalisir untuk memenuhi kebutuhan konsumen.

\section{B. Manajemen Logistik}

Manajemen logistik merupakan bagian dari manajemen rantai pasok pada perencanaan, pengimplementasian dan mengendalikan efisiensi, efektivitas untuk memenuhi kebutuhan pelanggan. Kinerja logistik ditentukan oleh efisiensi logistik (mencapai output yang diharapkan dengan sumber daya minimum), efektivitas logistik (mencapai persentase tertinggi dari output yang diharapkan) dan kompetensi logistik (menjadi kompeten dengan memperoleh nilai komparatif yang terbaik dan bersih) [7]. Dibutuhkan keefektivan dan keefisiensian dalam manajemen logistik pada rantai pasok untuk mengintegrasikan kegiatan logistik pada produsen, distributor dan konsumen sehingga memungkinkan produsen sawit Indonesia menjadi kompetitif di pasar [6]. Logistik merupakan komponen penting yang menghubungkan produksi dan pemasaran, sehingga mempengaruhi perekonomian nasional karena penambahan sumber daya. Meningkatnya kerja transportasi barang memiliki dampak langsung pada biaya logistik. Tingginya biaya logistik adalah salah satu faktor utama penghambat bahan bakar nabati dapat bersaing dengan bahan bakar minyak [4].

\section{Rantai Pasok yang Efektif dan Efisien}

Pendekatan manajemen rantai pasok berkembang seiring dengan meningkatnya kebutuhan dunia usaha untuk menekan biaya secara menyeluruh. Karena ruang lingkupnya mengelola aliran barang maka konsep manajemen rantai pasok banyak bersinggungan dengan manajemen logistic [8]. Adapun tujuan dari peningkatan rasio pemenuhan dan efisiensi yang ingin dicapai penulis, mengacu pada penelitian Mulyadi, yang menyarankan bahwa penetapan rantai pasok yang efektif dan efisien untuk komoditi strategis atau kebutuhan dasar (seperti beras, gula, tepung terigu, garam, minyak goreng, semen, pupuk, obat-obatan, bahan bakar, dan LPG), adalah sebagai berikut [8]: 
a. Mengefektifkan persediaan komoditas sehingga permintaan (biodiesel) dapat tercukupi, hal ini dapat ditinjau dari rasio pemenuhan yang berhasil dipenuhi;

b. Mengefisiensikan distribusi dan pabrikasi dalam rangka mendapatkan komoditas tersebut dengan harga yang terjangkau.

\section{Konsep Model dan Simulasi}

Model adalah representasi hasil dari dunia nyata. Pemodelan dibuat dalam gambaran yang sederhana, dengan melibatkan proses pemetaan masalah dari dunia nyata terhadap model pada dunia model. Sementara simulasi berisi penggambaran detail sistem atau operasi yang sedang diteliti atau dipelajari. Model sistem dinamik dibentuk karena adanya hubungan sebab-akibat (causal) yang mempengaruhi struktur dalam sistem, baik secara langsung antar dua struktur, maupun akibat dari berbagai hubungan yang terjadi pada sejumlah struktur, hingga membentuk umpan-balik (causal loop) [9].

\section{E. Simulasi Dalam Rantai Pasok}

Sebelum mempertaruhkan eksperimen dengan sistem supply chain yang nyata, simulasi menjadi tools yang berguna untuk memahami jaringan rantai pasok yang terdiri dari fungsi pengadaan material, tranformasi dari raw material menjadi finished product, hingga distribusi dari produk sudah jadi tersebut. Supply chain simulation menyiratkan model rantai pasok operasional representatif dengan mengamati proses tertentu dalam rantai pasokan yang nyata.

Penggunaan skenario untuk optimasi adalah salah satu metode tradisional untuk menangani kasus-kasus yang mengandung ketidakpastian. Supply chain simulation dapat menunjukkan bagaimana variabel-variabel penting dalam sistem saling berinteraksi. Hal ini juga dapat dimanfaatkan dalam melakukan percobaan dengan situasi atau rancangan skenario baru, dimana terdapat ketidakpastian berupa informasi, hingga decision rules yang ingin diterapkan [10].

\section{F. Proses Bisnis Rantai Pasok Biodiesel}

Jaringan rantai pasok terdiri dari banyak proses yang melibatkan berbagai pihak disepanjang rantai pasok biodiesel. Tahapan yang terjadi dalam sistem rantai pasok biodiesel terdiri dari produksi bahan baku (feedstock production), logistik bahan baku (feedstock logistic), produksi biodiesel (biofuels production), distribusi biodiesel (biofuels distribution) dan pengguna biodiesel (biofuels end use) [11], yang dapat dilihat pada Gambar 1.

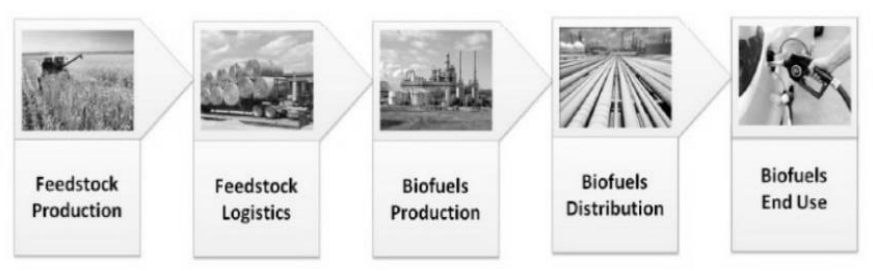

Gambar 1. Tahapan Rantai Pasok Biodiesel

\section{METODOLOGI}

Pengerjaan penelitian ini tersusun atas beberapa langkah yang sistematis. Langkah-langkah pengerjaan penelitian dari awal hingga akhir ditunjukkan pada Gambar 2.

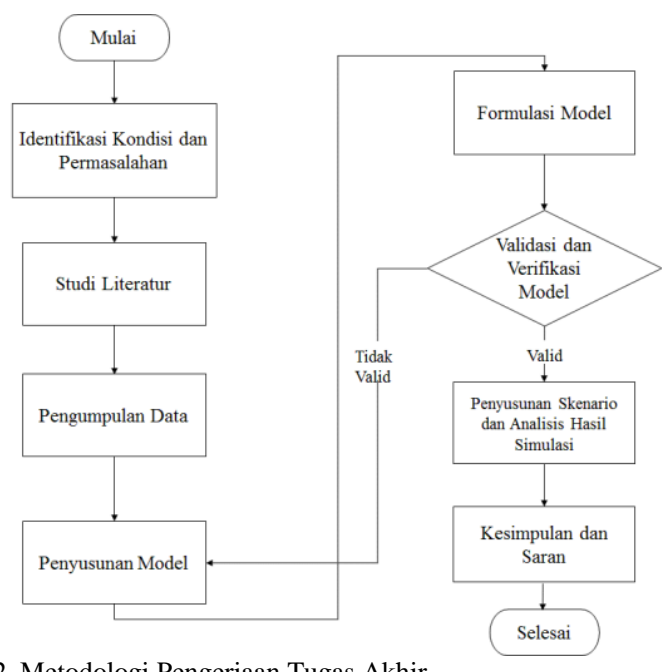

Gambar 2. Metodologi Pengerjaan Tugas Akhir

\section{MODEL DAN IMPLEMENTASI}

\section{A. Perancangan Model}

Dengan menggunakan metode simulasi sistem dinamik ini dibagi menjadi beberapa tahapan sebagai berikut:

a. Pembuatan diagram kausatik

b. Pembuatan diagram flow

c. Verifikasi dan validasi model

d. Pembuatan skenario dari model awal

Pemodelan dan simulasi pada penelitian ini digunakan untuk memodelkan ketersediaan biodiesel di Indonesia. Dengan memodelkan komoditas bahan bakar nabati, untuk meningkatkan swasembada energi (alternatif) nasional. Sehingga hasil simulasi dapat membantu dalam meningkatkan rasio pemenuhan biodisel dan efisiensi rantai pasoknya.

\section{B. Diagram Kausatik}

Awal dari pengembangan model ini adalah dengan melalui diagram kausatik atau yang biasa disebut dengan causal loop diagram. Hasil pemodelan diagram kausatik pada ketersediaan biodiesel untuk meningkatan rasio pemenuhan dan efisiensi manajemen rantai pasok, dapat dilihat pada Gambar 3 .

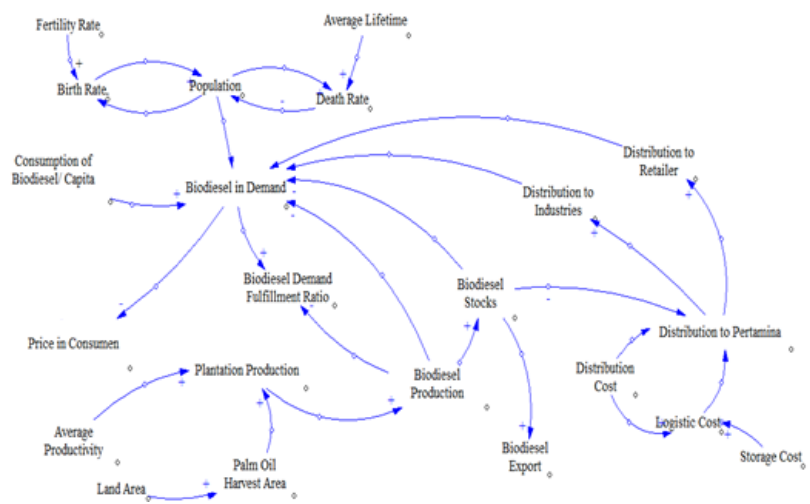

Gambar 3. Diagram Kausatik (Causal Loop Diagram) 


\section{Diagram Flow}

Tahap ini adalah membuat stock and flow diagram dari ketersediaan biodiesel untuk meningkatkan rasio pemenuhan dan efisiensi manajemen rantai pasok biodiesel nasional. Diagram flow dibuat untuk menggambarkan bagaimana jumlah produksi biodiesel dapat memenuhi permintaan konsumen. Dalam penyusunan diagram flow ini terdapat 7 sub-model diantaranya adalah sebagai berikut ini:
a. Sub-Model Population
b. Sub-Model Demand
c. Sub-Model Biodiesel Production
d. Sub-Model Biodiesel Inventory
e. Sub-Model Biodiesel Cost
f. Sub-Model Biodiesel Logistic Cost
g. Sub-Model Biodiesel Price in Consumen
D. Verifikasi dan Validasi

Setelah pembuatan model, tahap selanjutnya adalah pengujian model. Pengujian model mencakup dua tahapan penting, yaitu validasi dan verifikasi. Pada fase verifikasi model dilakukan proses pengecekan apakah model yang sudah dibuat telah merefleksikan model konseptual dengan jelas dan terbebas dari error. Verifikasi model harus dilakukan terutama untuk menghindari terjadinya kesalahan logika yang mungkin timbul, sehingga memastikan model dapat memberikan solusi yang masuk akal. Verifikasi model juga mencegah terjadinya kesalahan umum, seperti cakupan variabel yang kurang penting sementara variabel lain yang signifikan justru terabaikan.

Sedangkan validasi model, bertujuan untuk melihat apakah model sudah menggambarkan kondisi nyata atau tidak. Validasi model dilakukan setelah model simulasi diverifikasi. Pada tahap ini, proses pengujian model dilakukan. Suatu model dapat dikatakan valid ketika tidak memiliki perbedaan yang signifikan dengan sistem nyata yang diamati. Untuk dapat memastikan bahwa model sudah sesuai dengan kondisi existing, maka dilakukan validasi seperti pada Tabel 1. Dari tabel tersebut ditampilkan bahwa model dikatakan valid jika mean comparison $<5 \%$ dan error variance $<30 \%$.

Tabel 1.

Validasi Base Model

\begin{tabular}{ccc}
\hline \hline Variabel & Mean Comparison & Error Variance \\
\hline Populasi & $1,54 \%$ & $9,85 \%$ \\
Permintaan & $3,74 \%$ & $9,8 \%$ \\
Produksi Biodiesel & $4,8 \%$ & $6,9 \%$ \\
Produktivitas & & \\
\hline \hline
\end{tabular}

\section{PEMBUATAN SKENARIO DAN ANALISIS HASIL}

Setelah base model yang dibuat telah telah valid dan verified, tahapan berikutnya adalah skenariosasi, dimana skenario menjadi usulan perbaikan sistem, sesuai dengan tujuan awal dari pembuatan model sistem dinamik ketersediaan biodiesel nasional. Pembuatan skenario dapat dilakukan dengan menambahkan variabel dan parameter yang memiliki pengaruh dominan terhadap keseluruhan base model, untuk selanjutnya mengetahui dampak perubahan tersebut terhadap variabel lainnya. Skenario yang dibuat bertujuan untuk meningkatkan rasio pemenuhan biodiesel melalui peningkatan produktivitas biodiesel, serta tujuan skenario lainnya ialah meminimalisir biaya logistik dengan mengefisiensikan rantai distribusi biodiesel.

a. Skenario 1 (Parameter): Bertujuan untuk meningkatkan produksi biodiesel dengan mengubah nilai parameter rendemen sawit (Oil Extraction Rate)

b. Skenario 2 (Ekstensifikasi Lahan): Bertujuan untuk meningkatkan produksi biodiesel dengan membuka lahan tanam kelapa sawit yang baru.

c. Skenario 3 (Mengefisiensikan Rantai Distribusi): Bertujuan untuk meminimalisir biaya logistik yang timbul dan kian bertambah seiring panjangnya rantai distribusi biodiesel itu sendiri.

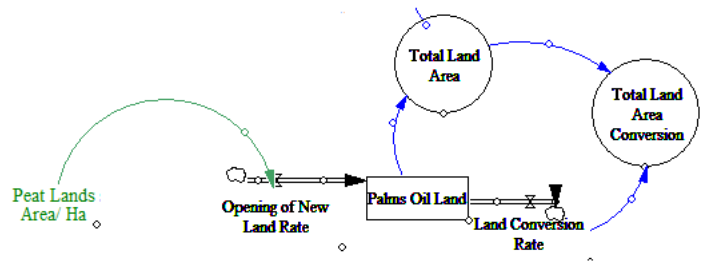

Gambar V. Sub-Model Skenario 2

Hasil dari skenariosasi yang telah dilakukan tergambar pada grafik yang ada pada Gambar 6 hingga Gambar 9, sebagai berikut:
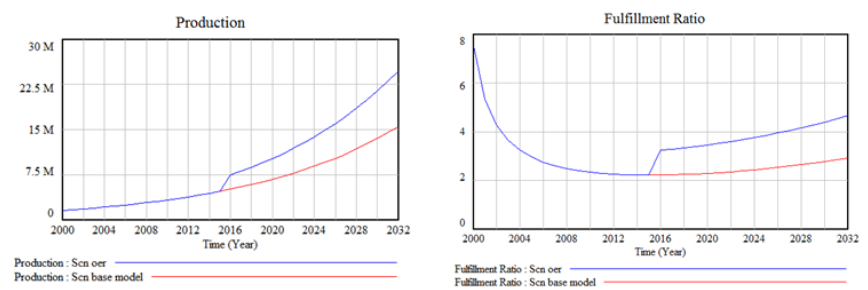

Gambar 6. Hasil dari Skenario 1 Peningkatan Nilai OER
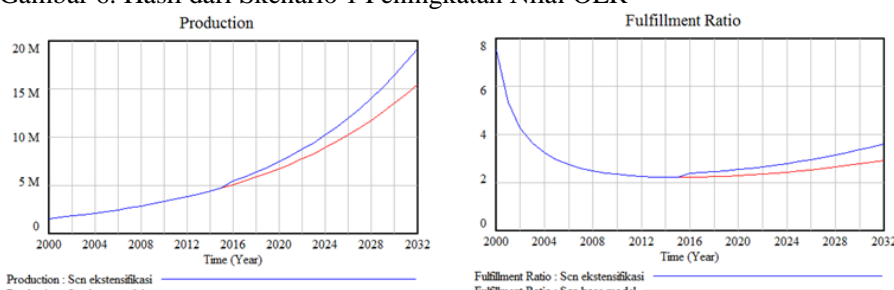

Gambar 7. Hasil dari Skenario 2 Ekstensifikasi Lahan
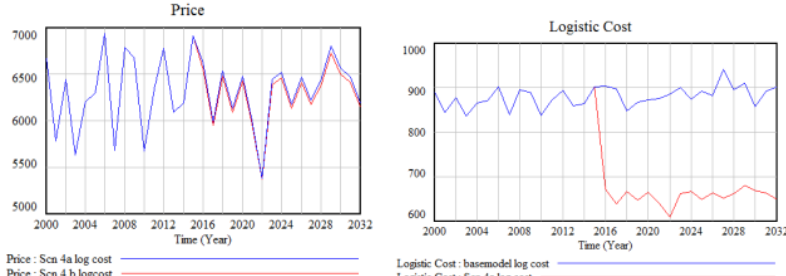

Gambar 8. Hasil dari Skenario 3 Efisiensi Rantai Distribusi 


\section{KESIMPULAN}

Dari pemodelan yang dirancang berdasarkan kondisi eksisting, faktor-faktor yang mempengaruhi rasio pemenuhan biodiesel, diantaranya adalah: Biodiesel Production dan Biodiesel Demand. Sedangkan faktor yang mempengaruhi efisiensi rantai pasok biodiesel ialah Total Logistic Cost, yang terdiri dari transportation cost dan storage cost (dari masingmasing pelaku atau aktor yang terlibat dalam proses distribusi biodiesel).

Model yang digunakan pada penelitian telah valid, karena telah memenuhi persyaratan nilai maksimal Error E1 (Means Comparison) sebesar < 5\% dan Error E2 (Amplitudo Variance Comparison $)<30 \%$. Sehingga model ini bisa dijadikan sebagai acuan untuk melakukan simulasi ketersediaan biodiesel dalam meningkatkan rasio pemenuhan dan efisiensi manajemen rantai pasok dan dapat dijadikan sebagai referensi dalam menentukan kebijakan.

Untuk dapat memperbaiki usulan perbaikan sistem, maka dilakukan pembuatan dan penerapan skenario untuk memenuhi ketersediaan biodiesel dengan meningkatkan rasio pemenuhan dan efisiensi manajemen rantai pasok. Skenario yang dilakukan antara lain: merubah nilai rendemen minyak sawit, menambahkan faktor lahan gambut kosong untuk ekstensifikasi lahan, dan mengurangi aktor distribusi biodiesel agar dapat meminimalisir biaya logistik dan harga yang ada di tingkat konsumen.

Hasil skenariosasi yang memberikan hasil optimal dalam meningkatkan rasio pemenuhan biodiesel adalah skenario merubah nilai parameter dari OER, untuk melihat apakah jumlah produksi minyak kelapa sawit olahan yang dihasilkan menjadi lebih optimal, sehingga mempengaruhi jumlah bahan baku pembuatan biodiesel. Berdasarkan perubahan parameter Oil Extraction Rate (OER) sebagai variabel dalam model, maka jika persentase OER dijadikan 20\%, maka produksi biodiesel mengalami peningkatan tiap tahunnya. Dengan rata-rata peningkatan produksi sampai tahun 2032 diprediksi mencapai 10,5 juta kiloliter. Sehingga skenario ini juga mampu meningkatkan rasio pemenuhan dari kondisi sebelumnya. Rasio pemenuhan mengalami kenaikan sebesar $13 \%$. Adapun kemungkinan kendala yang dihadapi untuk penerapan skenario ini adalah, dibutuhkan adanya perbaikan kualitas penanaman sawit dengan melakukan uji coba untuk mengoptimalisasi OER. Sedangkan hasil skenariosasi paling optimal untuk efisiensi rantai pasok biodiesel didapat dengan mengurangi biaya logistik antara perkebunan dengan pabrik. Persentase efisiensi atau perbedaan biaya logistik dengan kondisi terkininya, sebesar $15,7 \%$. Sedangkan harga biodiesel juga ikut terpengaruh dan memiliki perbandingan penurunan harga sebesar $2,77 \%$.

\section{SARAN}

Saran yang dapat digunakan untuk mengembangkan topik dan permasalahan dalam penelitian ini adalah konsep dan model dari ketersediaan biodiesel dapat diimplementasikan pada ketersediaan biodiesel di daerah lainnya, dengan dilakukan penyesuaian terhadap lingkup studi kasus yang diinginkan. Penelitian juga bisa memfokuskan pada ruang lingkup yang lebih kecil seperti provinsi, kota, dan lain sebagainya. Karena secara umum konsep distribusinya adalah sama. Selain itu, pengembangan model juga bisa lebih ditingkatkan dengan menjabarkan variabel harga di tingkat konsumen, serta biaya logistik yang dikeluarkan dengan lebih mendetail lagi, agar akurasi model yang dibuat lebih baik dalam mencerminkan kondisi nyata.

\section{DAFTAR PUSTAKA}

[1] D. R. A. H. and D. Putra, "Dinamika Jaringan Rantai Pasok Biodiesel dari Minyak Goreng Bekas," Universitas Andalas, 2015.

[2] S. J. \&. Yudiartono, Analisis Prakiraan Kebutuhan Energi Nasional Jangka Panjang di Indonesia. Jakarta: Pusat Pengkajian dan Penerapan Teknologi Konversi dan Konservasi Energi, Badan Pengkajian dan Penerapan Teknologi, 2005.

[3] S. H., "Analisis Kebijakan Mandatory Pemanfaatan Biodiesel di Indonesia," Universitas Indonesia, 2012.

[4] D. Finance, "Detik Finance," Detik Finance. [Online]. Available: http://finance.detik.com/ekonomi-bisnis/2663515/program-wajibsolar-dicampur-biodiesel-terkendala-infrastruktur?f9911033=.

[5] S. C. M. L. Li, Concepts, techniques and practices enhancing value through collaboration. Singapore: World Scientific Publishing Co. Pte. Ltd, 2007.

[6] C. Gimenez, "Logistics Integration Processes in the Food Industry," 2006.

[7] T. Bosona, "Integration of logistics network in local food supply chains," vol. 33, no. 1, pp. 32-48, 2013.

[8] D. Mulyadi, "Pengembangan Sistem Logistik Yang Efektif dan Efisien Dengan Pendekatan Supply Chain Management," 2011.

[9] F. C. and J. Mula, "Supply Chain Simulation, A system Dynamics Approach for Improving Performance," Springer, 2011.

[10] C. and Carillo, "Challenges of Introducing Simulation as a Decision Making Tool," in Proceeding of the Winter Simulation Conference.

[11] A. A. and H. V. Arani, "Biodiesel supply chain optimization via a hybrid system dynamics-mathematical programming approach," Elsevier, 2016. 